\title{
Impacts of Water Development Plans on Regional Water Cooperation-A Case Study of Amu River Basin
}

\author{
Haroon Ahmad Haleemzai ${ }^{1}$, Atiqullah Sediqi2 \\ ${ }^{1}$ Sharq Institute of Higher Education, Faculty of Sciences, Sharq, Kuwait \\ ${ }^{2}$ Directorate Academic Programs Development, Kunduz University, Kunduz, Afghanistan \\ Email: haleemzai1@gmail.com, atiqullahsediqi@gmail.com
}

How to cite this paper: Haleemzai, H.A. and Sediqi, A. (2018) Impacts of Water Development Plans on Regional Water Cooperation-A Case Study of Amu River Basin. Journal of Water Resource and Protection, 10, 1012-1030.

https://doi.org/10.4236/jwarp.2018.1010059

Received: July 5, 2018

Accepted: October 27, 2018

Published: October 30, 2018

Copyright $\odot 2018$ by authors and Scientific Research Publishing Inc. This work is licensed under the Creative Commons Attribution International License (CC BY 4.0).

http://creativecommons.org/licenses/by/4.0/

\begin{abstract}
The trans-boundary Amu River Basin (ARB), which is shared among Afghanistan, Kyrgyzstan, Tajikistan, Turkmenistan and Uzbekistan, is a primary source for human population and ecosystem. Future water demand in Afghanistan is likely to increase due to ambitious development plans after long-term unrest in the country. In accordance with high water abstraction in the Afghan part of ARB and its impacts on the downstream countries, water cooperation mechanisms are analyzed using the desk study approach. The results concerning regional water cooperation on the ARB show that, the level of cooperation between Afghanistan and central Asian riparian countries is reasonably weak. There are certain issues causing lack of cooperation between Afghanistan and central Asian riparian countries. Developmental and political interests of riparian states are key impediments to regional water cooperation on ARB. Technical impediments include the lack of human capacity, no application of basin approach and, lack of donor coordination at regional level. The policy analysis as a result of this study envisaged that initiatives to improve water management practices and increase productivity are highly needed in the study area to mitigate the foreseeing increase in irrigated water demand. The international framework law of UNWCC 1997 cannot be applied generally in central Asia and particularly in Afghanistan. Thirdly, Afghanistan's participation in regional water cooperation framework i.e. ICWC is highly needed though participation as permanent member requires a "revise water demand assessment by ICWC" on the basis of reliable data, current infrastructural development and irrigation expansion plans of Afghanistan albeit donor agencies could play a mediation role in establishing agreement on water allocation between Afghanistan and other riparian countries.
\end{abstract}




\section{Keywords}

Trans-Boundary, Water Demand, Water Cooperation, Impediments,

Policy Analysis, Legal Water Allocation

\section{Introduction}

The transboundary ARB, shared among Afghanistan, Tajikistan, Turkmenistan and Uzbekistan, is a primary source for the human population and ecosystem as well. Future developmental plans of Afghanistan and Tajikistan for developing their hydropower potential to cover their domestic energy demand will probably have declining impacts on water availability downstream for agriculture and ecosystem protection [1]. Also Afghanistan is a drought prone country. A severe drought is faced after there has been a low winter rainfall. A drought is faced in two consecutive years once every 10 - 15 years. Despite future agricultural and energy developmental plans, water allocation is also important with aspect to the mitigations for drought resistance.

Globally, many freshwater ecosystems are suffering from over abstraction [2]. Part of the Aral Sea has dried up due to high water abstraction from the Syr River. Infrastructural development plans in Afghanistan and Tajikistan have the potential for over abstraction leading to a drastic impact on water resources downstream.

The semi-arid to arid climatic conditions of the region create a high potential for water scarcity. This makes sustainable water management a major challenge in socio-economic development in the Amu River Basin. The future development of Tajikistan's and Afghanistan's vast water resources in the ARB that are to a large extent unregulated at the present time could affect downstream riparian countries. The effects could be many including an increase in the available regulated water resources, or the provision of additional hydropower, but could also include a decrease of available resources due to increased irrigation diversions upstream [3]. Also, future water supply is to a great extent uncertain due to potential withdrawal of water by Afghanistan. The potential of Afghanistan for water withdrawal is estimated up to $10 \mathrm{~km}^{3} /$ year [3].

\section{Study Area-Location and Characteristics}

The Amu River is formed by the confluence of the Panj and Vakhsh rivers which are the largest contributors. These two rivers contribute on average about $54 \mathrm{~km}^{3}$ annually, which is more than $80 \%$ of the main river annual flows [4]. All the riparian countries of the ARB highly depend on agriculture products for their livelihood and economy. This transboundary river basin sets the international border between Afghanistan and Tajikistan, and also between Afghanistan and Uzbekistan. The Amu river crosses Turkmenistan and for a large part traverses the length of Uzbekistan and its sub-region known as Karakalpakstan [5]. 
The Afghan part of ARB is located between longitude $68^{\circ} 01^{\prime} 49^{\prime \prime} \mathrm{E}$ and $74^{\circ} 40^{\prime} 30^{\prime \prime} \mathrm{E}$ and latitude $36^{\circ} 55^{\prime} 11^{\prime \prime} \mathrm{N}$ and $36^{\circ} 59^{\prime} 29^{\prime \prime} \mathrm{N}$. The total Afghan part belonging hydrographically to the ARB includes the northern basins and the Panj-Amu basin covering together $167,473 \mathrm{~km}^{2}$ [6]. The study area is composed of only the northeast part of the country covering an area of $90,693 \mathrm{~km}^{2}$ with a snow-covered area of $10,385 \mathrm{~km}^{2}$ [7]. The rest of $76,780 \mathrm{~km}^{2}$ lies under the Northern basin which is drained by the blind rivers of Khulm, Balkhab, Sar-i-Pul and Shirin Tagab discharging into the Dash-i Shortepa and does not reach the Amu Darya [8]. The total irrigated land in the study area is approximately $3540 \mathrm{~km}^{2}$. Further, about 57 percent of all the river-flows in Afghanistan originates from the ARB [9] Afghanistan's share of the total Amu Darya Basin is 31 percent. Geographic map of the ARB is provided in Figure 1.

\subsection{Population and Socio-Economics}

Around 43 million people depend for their livelihoods on the Amu river in the Aral Sea Basin. According to UNEP [4], the population in the study area is

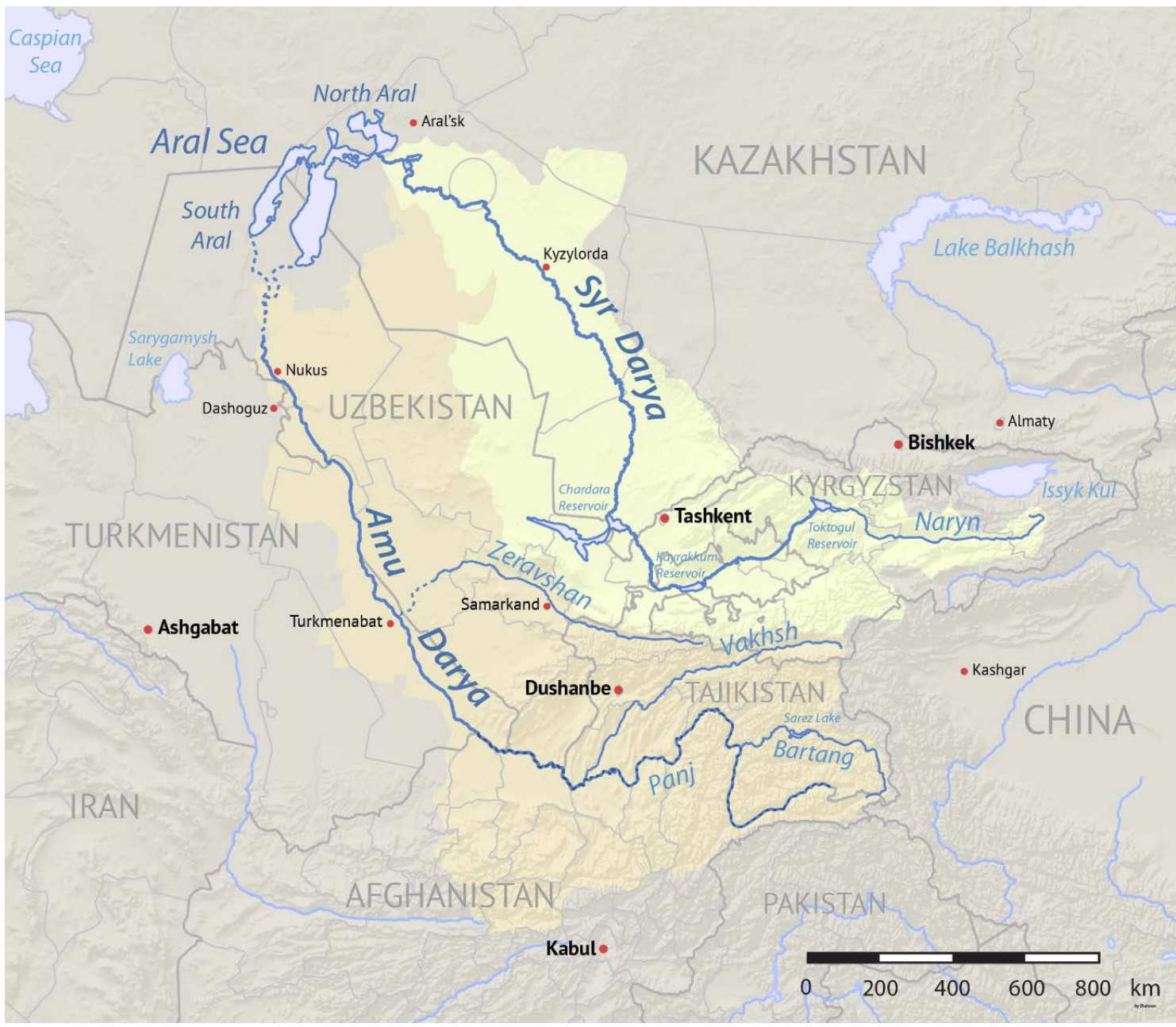

Source: https://en.wikipedia.org/wiki/Amu_Darya\#/media/File:Aral_Sea_watershed.png

Figure 1. Map of ARB. 
$2,968,122$. The population density in the study area is approximately 45 persons $/ \mathrm{km}^{2}$. The area of the basin within the country is $105,000 \mathrm{~km}^{2}$ [10] whereas AIMS [9] states that the area of ARB is $90,693 \mathrm{~km}^{2}$ and the population density is 33 persons $/ \mathrm{km}^{2}$. Balkh, Kunduz and Kokcha are the most densely populated watersheds of the study area. Since the dissolution of the Soviet Union, the population in the Afghan part of the Amu river basin has been doubled, increasing by 15 million people including returning refugees [4]. Information on the area and population of the AARB and its watersheds are given in Table 1.

\subsection{Hydrological Characteristics}

The total discharge of the Amu River is approximately $78.46 \mathrm{~km}^{3} / y e a r$. The discharge probabilities are $5 \%$ and $95 \%$ that is estimated at 108.4 and $46.9 \mathrm{~km}^{3} /$ year respectively [11]. The percentage flow generation of all five riparian countries according to [3] is shown in Figure 2.

\section{Water Allocation Systems in ARB}

There are many applicable agreements regarding water uses between Afghanistan

Table 1. AARB and its watershed-geographical and demographical data.

\begin{tabular}{ccccc}
\hline $\begin{array}{c}\text { Watershed/River } \\
\text { Basin }\end{array}$ & Area $\left(\mathbf{k m}^{2}\right)$ & $\begin{array}{c}\text { Number of } \\
\text { settlements }\end{array}$ & $\begin{array}{c}\text { Settled } \\
\text { Population }\end{array}$ & $\begin{array}{c}\text { Population Density } \\
\left(\text { per km }{ }^{2}\right)\end{array}$ \\
\hline Ab-i-Rustaq & 3670 & 231 & 358,749 & 97.74 \\
Khanabad & 11,994 & 622 & 668,938 & 55.77 \\
Kokcha & 22,368 & 1344 & 715,236 & 31.98 \\
Kunduz & 28,024 & 1240 & $1,090,639$ & 38.92 \\
Panj & 24,637 & 715 & 124,560 & 5.46 \\
Amu river basin & 90,693 & 4152 & $2,968,122$ & 45.97 \\
\hline
\end{tabular}

Source: Adopted from River basins and watersheds of Afghanistan, AIMS 2004 P-1.

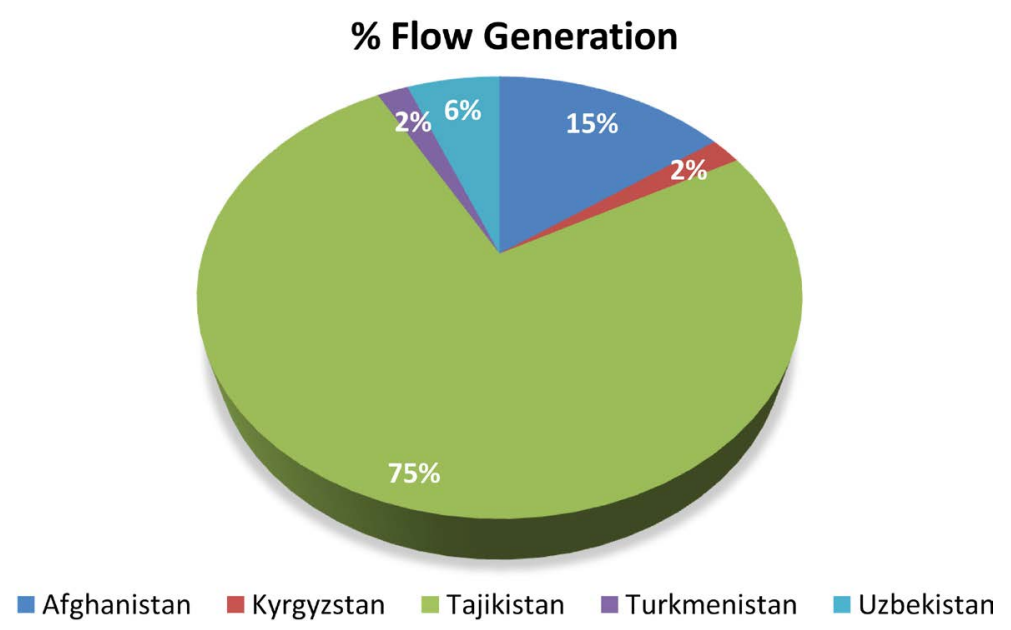

Source: Adopted from Research Action Plan Amu River (Schluter. M, Feb 2006), P-5.

Figure 2. Percent flow generation by all riparian countries in the ARB. 
and its central Asian riparians but these have not addressed obligations regarding water allocation [12]. Concerning internal water uses, it has been agreed between transboundary states that Afghanistan has territorial sovereignty on these resources. Currently, the waters of Khulm, Balkh, Sar-i Pul and Shirintagao rivers are all used for irrigation up to full extent [4].

Concerning the main Amu river and its tributaries (Panj, Kunduz, and Kokcha), according to ICWC (1970), Afghanistan may use and regulate water in the tributaries of the Panj and Amu Darya without consultation with other riparians, provided it meets restrictions limiting the release of pollutants [12]. Hence, the Vienna Convention's provisions maintain territorial integrity and boundaries between Afghanistan and the Central Asian riparians, but in issues of water relations the convention does not provide definite recommendations [12].

\section{Study Methodology}

Qualitative research involves the studied use and collection of a variety of empirical materials e.g. case study, personal experience, introspective, life history, interview, observational, historical, interactions and visual texts [13]. However, in this study qualitative research method is used for analyzing regional cooperation mechanisms concerning water resources of ARB. The data collection method adopted for qualitative research was desk study approach. Secondary data was collected through information from a diverse source of documents. The working papers used are project reports, case studies, conference proceedings, discussion papers/reports, and specific research reports on water cooperation in central Asia and Afghanistan.

The objective of qualitative data collection is analyzing water cooperation in AARB. Therefore, firstly cooperation level in ARB in relation to Afghanistan is analyzed, on the basis of existing agreements. Secondly, to analyze transboundary institutional frameworks and impact of high water abstraction on downstream riparian countries (Uzbekistan and Turkmenistan) data is collected using electronically stored information at various relevant websites e.g. ADBN and ICWC-CIS. One of the key limitations of this desk study approach is unavailability of reputable and reliable data. However, limitations associated with desk study approach are encountered during this study. For instance, reputable publications are used only, which has limited the number of to date publications. Since, this study is based on secondary research, recommendations for building effective cooperation mechanisms are limited.

\section{Analysis}

The situation on water cooperation has been analyzed highlighting prevailing challenges placing pressure on regional water cooperation. On the other hand regional and national policies and agreements are analyzed to understand prevailing challenges and opportunities in relation with regional water cooperation. 


\subsection{Situation Analysis}

A lot of literature believes that water availability downstream will be affected after implementation of irrigation rehabilitation and expansion plans in Afghanistan. The government of Afghanistan is also considering trans-boundary water policy as an instrument of cooperation and avoiding conflict with its neighboring riparian countries. In the ARB a number of seemingly unsolvable challenges are complicating progress towards better cooperation [14]. In accordance with the "Development Policy and Review Network" by the EastWest Institute and Wageningen University (2011), the existing issues in the ARB are mentioned below.

- Slowly growing culture of cooperation;

- Information deficit especially in Afghanistan;

- Lack of technical and human capacity;

- Failure to implement basin approach of water management;

- Lack of donor coordination.

Political will and commitment by all the riparian countries of the ARB at the highest possible level are important for successful cooperation concerning water-sharing [14]. Also according to McKinney D.C. [15] high level political will is required for achieving coordination that seems to lack in central Asia currently. There are many economic interests of the riparian states that are effecting cooperation on water resources management. For instance Tajikistan has planned the construction of the Rogun dam which if built will be the highest dam in the world. On the other side, Kyrgyzstan has started construction of Kambarata 2 dam. Uzbekistan is protesting about the construction of these dams [16]. There is a need for effective regional level policy to avoid these conflicts however, sustainable cooperative order, grounded in treaty level international law can be helpful [16]. Also the EU, in cooperation with donor agencies e.g. UNEP and $\mathrm{WB}$, as promoters of cooperation in water resources issues would be effective [16].

In CA the capacity issue for water management exists but is not as effective as it could be [15]. Therefore, human capacity is not as big issue as it is in Afghanistan. A big reason behind the lack of data in the region and particularly in Afghanistan is the lack of human, managerial and technical capacity [14]. This makes the position of Afghanistan weak in regional water negotiations and as a result there is weak cooperation.

The river basin approach in the ARB has not yet been fully applied because Afghanistan as a key riparian country still needs to be fully incorporated into all considerations relating to the basin [14]. The donor community, during their regional implementation of programmes and policymaking structures do not always reflect to Afghanistan therefore, the river basin approach is lacking in the region [14]. Inclusion of Afghanistan at technical level meetings will improve Afghanistan's hydro data and encourage interstate information sharing. It will also encourage contact between experts [14]. 
Many donor agencies are interested in investment in the ARB for constraints like sustainable use of water resources. The coordination level between these agencies is either at national level or weak at regional level [14]. This still needs to be strengthened through an effective mechanism. Also, according to EWI, poor information sharing between international donors concerning water-related development assistance is a large impediment in relation to enhancing regional water security [17]. Finally, coordination among donor agencies is desperately needed in regional water management activities of central Asia [15].

\subsection{Analysis of Cooperation Mechanism}

There are many approaches/mechanisms (suggested by a wide variety of literature) that can help in mitigating impacts on downstream countries and improve water cooperation. It is obvious that water disputes in central Asia are complex and can be solved by sustained, effective, institutionalized and principled negotiations. Therefore, existing agreements/treaties have been analyzed in search for cooperation on water resources management. According to Alborova A., (Head of the renewable energy sources, Tajik Technical University, Dushanbe), national solutions to the regional hydropower competition are long-term and development-minded which can be achieved by energy and water saving, and by the development of renewable sources of energy [18]. Some think that small hydropower plant development at the local level can help in saving energy.

Serious disputes on water in the region emphasize the need for a framework in which all interested parties should have confidence [19]. Therefore, international framework laws have been analyzed with reference to a best fit for cooperation on the ARB.

A variety of research thinks that water resources in the ARB are not scarce but lack of management of resources is creating the problem of water availability [17]. In addition, as many connections have been made between international water relations and regional relationships in general, it is likely that international water conflict and cooperation can also be influenced by domestic water events and vice versa [20]. Therefore, relationship between national water management practices and regional cooperation has been analyzed.

Therefore, current water management practices for irrigation efficiency and water saving has been analyzed particularly in the AARB.

There are many lessons learned concerning the role of donor agencies in transboundary water resources management. Donor agencies have played a vital role in coordinating riparian countries for arrangement and adjustments to their water policy framework. Therefore, the role of donor agencies in the ARB water resources management has also been analyzed.

\subsection{Analysis of Water Management in Afghanistan}

In accordance with the water law of the country, "water is a public good". This means that water usage is free but the water service provider can charge the us- 
ers for costs related to, supply storage, transfer, storage, diversion and treatment of water and other operational and maintenance activities relating to water distribution and irrigation systems. In accordance to article six of the water law priority has been given to drinking water and livelihood e.g. domestic food production. Integrated planning, management and development of water resources for sustainable supply and protection of water resources must be considered with due regard to the river basin approach and in accordance with the water law [21].

\subsection{Analysis of Water Management in the ARB}

Afghanistan and its central Asian neighbors are home to abundant water resources of which vast amounts are lost because of poor management [17]. World Bank Country Environmental Analysis (2007), states that "Irrational land management practices exacerbated by intermittent droughts" have resulted in many pockets of desertification, and between 96 - 100 percent of all national rangelands are degraded [8]. Therefore, improvement in irrigation efficiency and practices is vital for water conservation. By improving irrigation drainage system in Uzbekistan and Turkmenistan $8 \mathrm{~km}^{3}$ of water per year could be saved [8].

In Afghanistan about $85 \%$ of all crops are produced under the irrigation system. Currently the irrigation efficiency in the country is about $25 \%$ whereas the international norm for efficient irrigation systems is about 40\% [22]. In addition to this initiative there are many irrigation modernization and rehabilitation programmes going on in Afghanistan including its northeast basin (ARB). Currently a total area of 50,000 ha of land is being rehabilitated within the study area. With this rehabilitation, the total active irrigated area is 250,000 ha and 135,000 ha is left for rehabilitation and modernization [8].

\section{Policy Analysis}

\subsection{Water Framework Policy of Afghanistan}

In accordance with the "Strategic Policy Framework for the Water Sector" the vision is to improve the livelihood of the society by developing and implementing integrated water resources management with sustainable use of the water resources, based on widely acceptable socio-economic, environmental norms and standards [23]. Hence, the goal of "water framework policy" is to develop and manage water resources in a sustainable manner, through active involvement of all stakeholders to secure and improve livelihoods, the environment and support the national economic development.

There are many policies related to water resources management. According to ANDS (2007), all the below mentioned policies have been approved by SCWAM as national policies [24].

- Water resources policy and regulations, for both surface and groundwater resources;

- Institutional framework for water resources management; 
- Irrigation policy and regulations (small and medium community-based and medium and large scale public irrigation facilities);

- Charters and internal regulations for water user associations;

- National urban and rural water supply and sanitation policies and institutional development;

- Hydropower development policy.

\subsection{Institutional Arrangement for Water Resources Management in Afghanistan}

In accordance to water resources management policy, MEW is entitled as regulator and facilitator and will be directly responsible for national planning, establishing laws, policies and strategies, institutional development policies, and coordination with other parties involved in the water sector.

\subsection{Institutional Framework in Afghanistan for Regional Cooperation}

The Afghan government drafted its trans-boundary water policy in 2006 to ensure sufficient water resources were available for its sustainable development. However, this policy has never been approved by the parliament. However, according to the prepared draft policy, an institutional framework for managing transboundary water has been developed. According to this policy, all agreements on water allocation and sharing will be signed by the president and approved by the Parliament. Negotiations on water-related agreements and treaties will be done by the First Vice President and Ministry of Foreign Affairs. SWCAM will play an advisory role on such agreements. The relevant ministries will be responsible for the provision of technical information and development programmes. The National Water Secretariat (NWS) will work under the supervision of SCWAM and directions received by the First Vice President. NWS will coordinate with ministries on a development review, information, and water resources data that will help in establishing water agreements, treaties, and memorandum of cooperation. Ministries are responsible for establishing working groups, memorandum of cooperation and meetings with their counterparts in neighboring countries and share information with SCWAM and the secretariat. An institutional framework on trans-boundary water policy allows the participation of third parties (donors, impartial agency or country) as an advisory group for resolving disputes on water allocation, management policies and agreements with neighboring country/countries. The National Water secretariat is responsible for technical support to the third party [25].

\subsection{Central Asian Institutional Framework for Regional Water Cooperation}

Almay agreement is the first inter-state agreement between CA states. ICWC was established under this agreement. Initially, ICWC was assigned responsible for joint water resources management. The ICWC consists of a council having 
four senior members of water management organization from every founder states. Later on IFAS was introduced in institutional framework of regional water cooperation.

The IFAS is the current top decision-making body concerning water resources management. This board is composed of Deputy Prime Ministers from the five member states, with portfolios involving agriculture, water and environment. Leadership is rotated every two years among the presidents of the five countries. The board meets three times per year to discuss the views of member states and to decide on the policies, programs, and institutional proposals. The IFAS also has a separate body for daily operations named the "Executive Committee" of IFAS. The executive committee recommends programs, policies and proposals forwarded by member states to the IFAS board.

The ICWC remains the highest technical level organ and has four executive bodies (the secretariat, the two BWOs, and the SIC). In practice, the SIC prepares all technical, financial, institutional, and legal proposals probably in cooperation with the respective member ministries. After approval of a proposal by the ICWC, it is transferred to the IFAS for endorsement. The ICWC is also responsible for management of transboundary water resources with respect to interstate agreements e.g. distribution of annual water limits to parties and the Aral sea, development of measures to maintain the regimes of water supply and distribution [19]. Two BWOs and SIC are working under ICWC. The primary task of the Amu Darya BWO is to control transboundary water resources.

\subsection{Relevance to ICWC Framework}

There are many justifications for involving Afghanistan in the activities of the ICWC [26]. Also, according to DPRN [14], most discussants agree that currently Afghanistan should be included in regional water structures at technical level. In addition, future central Asian water management initiatives will probably take into account Afghanistan's water demands [27]. Therefore, Afghanistan inclusion in ICWC is of vital importance particularly with regard to being a high water abstractor in the coming decade.

One of the primary goals of the ICWC is equitable water allocation and the concept of shared water rights and responsibilities. Exclusion of Afghanistan from the ICWC can be an indication of the lack of commitment of the central Asian riparian countries on water cooperation in the region [28]. Therefore, for the effectiveness of the ICWC, it is required to ensure that different interests from the different riparian states are equally presented [29].

In 2002, ICWC considered the irrigation development plans in Afghanistan and reviewed the rights of Afghanistan to divert water from the Amu Darya [30]. Firstly, irrigated area expansion in accordance with the North Afghanistan irrigation development plan was taken into account. Irrigated land in 2005 was assumed the same as in 1965 as there was no expansion due to unrest in the country. The expansion in irrigated land is considered 153,000 hectares until year 
2040.

\section{Analysis of Transboundary Agreements on Water Resources Management}

Many agreements on the Amu river basin exist between riparian countries especially among central Asian countries. Some of these agreements are still applicable.

\subsection{Agreements among Central Asian Riparian Countries on the ARB}

Protocol 566 (under the agreement of 12 March 1987) is still applicable among central Asian countries. This agreement was endorsed by all four central Asian riparian countries (Tajikistan, Uzbekistan, Kazakhstan and Turkmenistan). The significance of this agreement is that it is still the main agreement for water allocation among these four states. It was agreed that the total amount of extraction from the ARB should be limited to $61.5 \mathrm{~km}^{3} /$ year. Water uses of Afghanis$\tan$ are assumed $2.1 \mathrm{~km}^{3} /$ year in this agreement [12]. Protocol 566 was agreed to limit water resources in the Amu River basically to solve the water crisis in the Aral Sea. The groundwater resources were not taken into account in this agreement.

The trans-boundary water resources of the Aral Sea basins (the Amu River and Syr River) are still allocated among five riparian states (Tajikistan, Kyrgyzstan, Uzbekistan, Turkmenistan and Kazakhstan) of the former Soviet Union on the basis of a quota system developed during the Soviet era in September 1987. The quota system was developed mainly for reaching irrigation water needs and will remain valid until a regional water resources management strategy is formulated (Almaty Agreement, 1992). In the Almaty agreement the parties agreed to maintain and adhere to the division of the transboundary water resources as set out in Protocol 566 for the Amu Darya. Under the same agreement an Interstate Commission for Water Coordination (ICWC) was established. This Commission was assigned as the body responsible for definition of seasonal allocations in line with the annual agreement. It was also agreed by parties that the Basin Water Organizations (BWO) Syr Darya and BWO Amu Darya would be incorporated into the ICWC structure as the implementing agencies responsible for the control of water allocation [12].

\subsection{Agreements between Afghanistan and Central Asian Riparian Countries}

There are many agreements between Afghanistan and the Soviet Union during the $19^{\text {th }}$ and $20^{\text {th }}$ centuries related to the Amu River. Most of these agreements are about frontier demarcation and water resource uses. Three important agreements with aspect to the significance of the Amu River are as below:

1) Frontier agreement of 1873 between Afghanistan and Russia;

2) Frontier agreement of 1946 between Afghanistan and the USSR; 
3) Treaty between the Royal government of Afghanistan and government of the USSR of 1958 called the "Complex use of Amu Darya transboundary water resources".

The treaty of 1958 is of significant importance concerning water resources use and management. Article 16 of this treaty clearly explains that any infrastructural development or usage of frontier water (Panj and Amu Darya) is not allowed without agreement of the contracting party. In this treaty, it has also been agreed by both parties (Afghanistan and USSR) that this treaty will not apply to national internal waters. In accordance with the 1958 treaty, Afghanistan and USSR entered into an agreement on 19 June 1964. According to this agreement any construction work on the Panj and Amu Darya by Afghanistan or central Asian riparian countries is prohibited without consultation. According to this agreement, Afghanistan can use and regulate water on tributaries of the Panj and Amu Darya for its needs only, providing to limit discharge of pollutants in the main river. However, no obligations concerning water allocation have been addressed in this agreement [12]. In accordance with the trans-boundary water policy of Afghanistan, except for the Helmand River, Afghanistan has no agreements with neighboring nations on transboundary water [25]. Nevertheless, since the breakdown of the Soviet Union, according to customary water law, boundary agreements of the predeceased state remain unaffected by succession. Therefore, existing agreements between Afghanistan and the USSR are still applicable to the former soviet republics. But, there is no historical confirmation on the water allocation of the Amu River in the Afghan part [12].

Afghanistan sent a delegation to Tashkent to identify its share of the Amu River in 1977. The delegation had proposed $9 \mathrm{~km}^{3} /$ year but the Soviet Union offered only $6 \mathrm{~km}^{3} /$ year [10]. This agreement could not take place either.

\subsection{Rights, Interest and Responsibilities of Afghanistan and CA Riparian Countries Concerning ARB}

In all agreements between Afghanistan and USSR, water allocation to riparian countries (sharing water resources) is not considered. However, in accordance with the 1958 agreement, there are some rights and obligations to Afghanistan. Also since the breaking up of the Soviet Union in 1992, there are additional water agreements among central Asian independent states on water allocation and uses. After several draft agreements, the parties accepted the IFAS as the leading decision-making and financial body with one executive committee (EC IFAS) and the ICWC as the technical body with four executive bodies.

In contrast to the obligations for regional sustainability and ecosystem protection, there are some economic and development interests of the states. For instance, the republic of Tajikistan has two main objectives. Firstly, like other riparian countries it intends to expand its irrigated land, possibly by intakes from the Zeravshan river e.g. Tajikistan increased its irrigated area by 200,000 ha since independence and it would like to increase it further [27]. Secondly, it intends to increase hydropower capacity for domestic use as well as to export to other 
countries. However, other riparians are more concerned by Tajikistan's second objective [27]. The Kyrgyz government intends to increase its hydropower generating capacity whereas the second goal is to develop agriculture production to comply with its domestic demand. The Kyrgyz government's water abstraction from the ARB is of less concern in the region.

However, there are some objections by downstream countries concerning dams located in the Syr river basin. Turkmenistan's primary objective concerning water management is ensuring food security [27]. This country wants to increase 450,000 ha of land under irrigation by reusing drainage and run-off water. Turkmenistan and Uzbekistan both rely almost totally on the Amu Darya for their irrigation [27]. Uzbekistan has achieved its food self-sufficiency and now it is developing additional irrigated areas in order to produce consumptive and cash crops for exporting.

Afghanistan after the civil war intends to rehabilitate its irrigated agriculture. Its primary objective is to extend its irrigated areas from the current level of 408,324 ha to 549,112 ha by 2025 . The secondary objective is to increase its hydropower generation potential (to reach the country's domestic energy demands) by constructing hydropower dams. Upstream riparians of the ARB see the water resources as a source of hydropower and electricity whereas downstream riparian see it as a primarily source of irrigation water for cotton and rice production [28].

\subsection{Relevance of 1997 UN Convention to the Agreements between Afghanistan and Central Asian Riparian Countries on the ARB}

The UN water convention on the law of the non-navigational uses of international watercourses is a universal framework instrument. This framework convention spells out its relationship with existing and future watercourse agreements. This convention has not been signed by any of the ARB riparian countries except Uzbekistan. This convention as a source for cooperation between central Asian riparian countries and Afghanistan on shared water resources is analyzed on the basis of primary principles of 1997 UNWCC. This convention's basic principles of no-harm, information exchange, emergency cooperation and prior notification are also mentioned in the 1958 Soviet-Afghan agreement though in very general terms.

However, other principles of this convention like duty to cooperate, monitoring, assessment, and dispute settlement are not considered in any post-Soviet-Afghan agreement/treaty. Nonetheless, these later principles are considered in the 1992 Almaty agreements. Provisions of the Almaty agreement relevant to 1997 UNWCC include the following obligations [19].

1) Cooperation to attain optimal utilization and adequate protection of the international watercourse;

2) Protection of the ecosystem through the prevention, reduction and control of pollution; 
3) Entering into consultation concerning the management of the international watercourse.

All existing agreements deal with only surface water whereas the UNWCC defines a watercourse as a system of surface and ground water which is another big contradiction between existing agreements and the UNWCC 1997. Also, the UNWCC cannot be enforced in central Asia because the rights and duties of the central Asian states over the shared rivers is governed by customary international law [16].

In conclusion, transboundary cooperation, through the UNWCC, on water resources of the ARB between Afghanistan and central Asian riparian countries is not possible at this moment. However, the possibility of joining the ICWC should be considered and evaluated in terms of multilateral benefits.

\section{Analysis of Regions' Cooperation/Conflict with Afghanistan on the ARB}

\subsection{Afghanistan's Absence in Regional Meetings/Conferences on the ARB Water Resources Management}

In the past, Afghanistan has been ignored by all transboundary riparian countries in agreements, conferences and meeting related to the ARB. The reason behind this is considered the limited water use in northern Afghanistan and therefore there was no need for agreement on the issue [12]. Also reliable data on water use in Afghanistan from the Amu River does not exists however it is estimated to be about $2 \mathrm{~km}^{3} /$ year or 3 percent of average annual river discharge [4]. Another reason for ignoring Afghanistan during 1991-96 is the Taliban regime. The central Asian states had not formally recognized the Taliban government. Hence, it was not included in meetings and agreements on the Amu River. Another reason for Afghanistan's exclusion is that cooperation with Kabul is not a priority for any of the ARB (Central Asian) riparian countries [28]. Moreover, recognizing Afghanistan's legitimate water rights and responsibilities by its fellow riparian neighbours has not improved since 1987 and possibly not since 1958. Also "neither the central Asian states" independence nor the establishment of the Karzai government in Kabul was seized as an opportunity to recast regional water structures [28]. This is considered as another reason of ignoring Afghanistan from Soviet and post-Soviet water allocation agreements. However, recently Afghanistan has been engaged with the water convention at the meeting of the parties in 2009 and the EU, central Asia and Afghanistan consultation over shared water resources in 2010. In addition, regional meetings between Afghanistan and Tajikistan in November 2007 and field visits to basin area of both counties have been made in early 2008 .

\subsection{Possible Conflict/Cooperation Due to High Water Abstraction Upstream}

The possibility to negatively influence neighbouring countries' water availability 
after the implementation of irrigation and dam development plans is high [1]. Further the project of Upper Amu Darya that started in 2008 and anticipates the development of 500,000 hectares of agricultural land [1]. Additionally, Afghanistan's implementation of its 2008 WSS and in particular its major infrastructure plans, will have significant impact on water supplies in central Asia. Government and US policies have increased productivity without considering downstream impacts of those policies [31].

However, little is known about the impacts that irrigation development could have on Amu River which flows from Afghanistan to central Asia. Investment in managing the demand for irrigation water in the upstream is very important in avoiding conflict and seeking cooperation. Therefore, to realize their collective interest in regional stability, water security, and tapping into new markets to the south, the central Asian states must engage Afghanistan [10].

On the other hand, the government of Afghanistan has recently considered the importance of transboundary water resource management and is seeking to make a transboundary water policy. MEW initiated the process of transboundary water resources policy in April 2007. The draft policy was developed by MEW in 2007. In accordance with Afghanistan's draft policy on transboundary water resources, Afghanistan would impact downstream users because of the following two major reasons [25].

- High-energy demand in the ARB occurs in winter, therefore hydropower development redirects flow to the winter months. On the other hand, irrigation demand peaks in summer; irrigation dams store water for release during the irrigation season.

- Tajikistan is planning to build two hydropower dams on the Panj River (border between Afghanistan and Tajikistan) namely, the Dasht-i-jum and the Upper Amu River; both projects will require water agreements with Afghanistan.

\subsection{Afghan and Central Asian Cooperation Concerning the ARB}

Afghanistan's interest in the water resources of the ARB have increased and this increase has recently gained prominence in the international community [31]. Lack of data on water consumption, limited access to collect this data and unrest have rendered challenging discussions on water cooperation between Afghanistan and its neighbors [31]. The importance for Afghanistan in regional water cooperation is widely accepted both by governmental and donor counterparts. After the civil war in Afghanistan, it will be naïve to think that Afghanistan will rehabilitate its agriculture without increasing its abstraction from the rivers it shares with central Asian countries [27]. According to Ambassador Miroslav Jenca (special representative of the Secretary-General for Central Asia and Head of the UNRCCA), central Asian states have shown willingness to cooperate among them and to widen dialogue on including regional stakeholders such as Afghanistan into the regional framework [17]. Also the UNAMA will be taking 
initiatives to further explore this possibility.

The degree of cooperation between Afghanistan and Tajikistan has increased, after the civil war in Afghanistan. There are considerable bilateral water cooperation and development projects. However, these agreements are general and some actions are required concerning water management.

\section{Analysis Concerning Role of Donor Agencies/International Community in Regional Water Cooperation}

Since the independence of post-Soviet states, the international community has played an active role in water issues of central Asia [16]. Many projects are implemented by donor agencies. Most of these implemented projects are technical (capacity building, irrigation water and, drinking water) [16]. However, some of the earlier projects have also focused deeply on trans-boundary water issues in central Asia e.g. Water Resources Management and Agricultural Production Project (WARMAP). These projects have not produced any effective results [16].

There is an ongoing tension, notably between Uzbekistan and Tajikistan concerning the construction of the Rogun Dam [14]. On the other hand, Kyrgyzstan has started construction of the Kambarata 2 dam. Uzbekistan is protesting about the construction of these dams [16]. It thinks that construction of dams in upstream will threat water availability in summer when its irrigation water demand is high. Russia is a major trading partner with Uzbekistan, and therefore, in the matter of the Rogun Dam construction, it finds itself in a tricky position. The other regional power is china. China has voted against the Watercourse Convention and concerning the use of shared Central Asian watercourses [16]. Current and planned uses from the transboundary Iyrtush and Illi Rivers by China will probably have major adverse impacts downstream in Kazakhstan [16].

Hence, the role of neighboring countries, for instance, Russia and China in solving Tajik-Uzbek and Kazak-Uzbek tension on the construction of hydropower dams, is considered ineffective.

In the ARB a number of technical activities and projects have been implemented so far. The list of projects and funds disbursed since 2002 in the Aral Sea Basin is given in Annex 4. It is evident that around 60 and 251 million US dollars have been contributed by donor agencies as fund and loans respectively. However, regional cooperation is unlikely to be achieved through these projects [15].

The need for adjustments to existing regulations under the Almaty agreement to achieve sustainable water management is widely accepted [32]. Future water management will highly depend on changing needs in agriculture, the demand of the ecosystems in the deltas, littoral of the Aral Sea, potential increase in water intake from Afghanistan, effects of climate change and other physical or socio-economic factors [33]. As Afghanistan is an upstream riparian country, sharing with Tajikistan many tributaries of the Amu Darya, it is also crucial that the central Asian republics negotiate agreements on equitable utilization of the ARB water resources [19]. 
The donor agencies can play a vital role in restructuring the institutional framework of the Aral Sea Basin as they did in other transboundary river basins e.g. the Mekong River Basin (MRB). In the MRB, assistance of the UNDP concerning negotiation proved most useful to the parties for reaching consensus on a new framework of cooperation [34]. In the ARB there is a great stress between water uses for agriculture and energy generation. In the MRB this problem has been faced and handled by adopting a multi-sectoral approach [15]. Other experts are also in favour of involving multi-sectors for water cooperation. Regional cooperation is possible by convincing the riparian countries on the benefits of participation in the development of joint, coordinated projects. Also introducing policies that bring benefits or decrease damages, will encourage multiple participants for joint and coordinated activities [15].

\section{Conclusions}

The results of this study showed that there are certain issues that may influence cooperation level between Afghanistan and the central Asian riparian countries. With the aim to overwhelm the existing causes for lack of cooperation, initiatives are required concerning reliable and easily accessible hydrological and/or agricultural data in AARB. Lack of human and technical capacity is one of the major reasons that have seized approval of transboundary water policy of the country. Therefore, technical and human capacity also needs to be developed through certain projects in the AARB. Also information dissemination at the regional level on projects implemented by donor agencies is highly required to facilitate regional cooperation.

There are certain limitations concerning irrigated agricultural data availability. Agreement can only be facilitated by having hydrological information in AARB for allocating equitable water rights to Afghanistan. Therefore, further studies are required for assessing reliable data on river discharges, change in flow regime due to snow melting, and updated meteorological characteristics of study area. For this reason agricultural survey in the country, particularly in the AARB is very important to get reliable agricultural data that will help assessing significant results concerning water demand.

The results concerning cooperation/conflict intensity between Afghanistan and central Asian countries reveal that cooperation level is very low. It was found that the cooperation can be improved through negotiations for determining legal water rights of Afghanistan from ARB. Further cooperation should be improved to mitigate the possibility of future tensions on water resources use of the ARB.

Concerning strategic options to avoid conflict with downstream riparians and strengthen cooperation on water resources management, the study recongizes certain effective mechanisms. Afghanistan's joining the ICWC framework has highly been accepted. It was found that Afghanistan can become permanent member of ICWC after revised assessment on water demand of Afghanistan, 
which must be based on reliable hydrological and irrigated agricultural data. Also current plans should be considered in contrast to pre-war hydropower and irrigation development plans.

Since, interests of riparian states on water resources uses in upstream of the ARB have changed therefore, regional agreement between central Asian states should be revised in consideration to interests of Afghanistan for equitable uses of water resources by all countries.

The study realizes that donor agencies can play a vital role in restructuring of the ICWC regarding current change in priority for water uses (hydropower generation) and strengthening coordinating for establishing agreement between Afghanistan and its neighboring riparian countries.

\section{Conflicts of Interest}

The authors declare no conflicts of interest regarding the publication of this paper.

\section{References}

[1] Wegerich, K. (2009) Water Strategy Meets Local Reality. AREU, Kabul.

[2] Quesne, T.L., Pegram, G. and Heyden, C.V.D. (2007) Allocating Scarce Water: A Primer on Water Allocation, Water Rights and Water Markets. WWF.

[3] Schluter, M. (2006) Research Action Plan Amu River.

[4] UNEP (2011) Environment and Security in the Amu Darya Basin.

[5] Glantz, M.H. (2005) Water, Climate and Development Iissues in the Amu Darya Basin. Mitigation and Adaptation Strategies for Global Change, 10, 23-50.

[6] Shobai, S.S. (2001) Organization and Management of Irrigation Waters, Crop Water Requirement. FAO, Peshawar.

[7] Favre, R. (2004) Watershed Atlas of Afghanistan. 1st Edition, Working Paper for planners Afghanistan Research and Evaluation Unit, Kabul.

[8] Klemm, W. and Shobair, S.S. (2011) The Afghan Part of Amu Darya Basin, Impact of Irrigation in Northern Afghanistan on Water Use in the Amu Darya Basin.

[9] AIMS (2004) River Basins and Watersheds of Afghanistan. AIMS FAO, Kabul, 7.

[10] King, M. and Sturtewage, B. (2010) Making the Most of Afghanistan's River Basins Oppertunities for Regional Cooperation East West Institute.

[11] Crosa, G., Froebrich, J., Nikolanyenko, V., Stefani, F., Galli, P. and Calaman, D. (2006) Spatial and Seasonal Variations in the Water Quality of the Amu Darya River (Central Asia). Water Research, 40, 2237-2245.

[12] Ahmad, M. and Wasiq, M. (2004) Water Resources Development in Northern Afghanistan and Its Implications for Amu Darya Basin. World Bank Working Paper No. 36, World Bank, Washington DC.

[13] Newman, I. and Benz, C.R. (1998) Qualitative-Quantitative Research Methodology: Exploring the Interactive Continuum. Southern Illinois University, Carbondale.

[14] DPRN (2011) The Afghan-Central Asian Water Cooperation on Management of the Amu Darya River: Connecting Experts and Policy Makers in the Low Lands. 14.

[15] McKinney, D.C. (2003) Cooperative Management of Transboundary Water Resources in Central Asia. 4th Draft. 
[16] Hodson, S. (2010) Strategic Water Resources in Central Asia: In Search of a New International Legal Order.

[17] EWI (2009) Alternative Futures for Afghanistan and the Stability of Southwest Asia: Improving Regional Cooperation on Water.

[18] Mirimanova, N. (2009) Regional Cooperation and Its Alternatives as Solution Paths for the Water and Energy Disputes in Central Asia. Water and Energy Disputes of Central Asia: In Search of Regional Solution?

[19] Vinogradov, S. and Langford, V.P.E. (2001) Managing Transboundary Water Resources in the Aral Sea Basin: In Search of a Solution.

[20] Giordano, M., Griordano, M. and Wolf, A. (2002) The Geography of Water Conflict and Cooperation: Internal Pressures and International Manifestations. The Geographical Journal, 168, 293-312.

[21] MEW (2009) Water Law. Official Gazzette, Kabul.

[22] Aini, A. (2006) Water Conservation in Afghanistan, Kabul.

[23] MIWRE (2004) Water Resources Management Policy Ministry of Irrigation, Water Resources and Environment, Kabul. 23.

[24] Mahmoodi, S.M. (2008) Integrated Water Resources Management for Rural Development and Environmental Protection in Afghanistan. 11.

[25] MEW (2007) Transboundary Water Policy of Afghanistan MEW.

[26] Dukhovny, V.A. and Sokolov, V. (2003) Lessons on Cooperation Building to Manage Water Conflicts in the Aral Sea Basin.

[27] Allouche, J. (2007) The Governance of Central Asian Waters: National Interests versus Regional Cooperation.

[28] Horsman, S. (2008) Afghanistan and Transboundary Water Management on the Amu Darya: A Political History.

[29] Weinthal, E. (2006) Water Conflict and Cooperation in Central Asia. Human Development Report Office 2006/32.

[30] Dukhovny, V.A. and Schutter, J.L.G. (2011) Water in Central Asia: Past, Present, Future. CRC Press, Boca Raton.

[31] CFRUSS (2011) Avoiding Water Wars; Water Scarcity and Central Asia’s Growing Importance for Stability in Afghanistan and Pakistan. Committee on Foreign Relations, Washington DC, 28.

[32] Dukhovny, V.A. and Sokolov, V.I. Integrated Water Resources Management in the Aral Sea Basin.

[33] Schluter, M., Savitsky, A.G., McKinney, D.C. and Lieth, H. (2004) Optimizing Long-Term Water Allocation in the Amudarya River Delta-A Water Management Model for Ecological Impact Assessment.

[34] Moigne, G.L. (2004) Past Experience and Future Challenges, Cooperation in Shared Water Resources Management in Central Asia. ADB, Almaty. 